\title{
The fate of U1 snRNP during anti-Fas induced apoptosis: specific cleavage of the U1 snRNA molecule
}

\author{
WGJ Degen ${ }^{\star,}$, Y van Aarssen ${ }^{1}$, GJM Pruijn ${ }^{1}$, PJ Utz $^{2}$ and \\ WJ van Venrooij ${ }^{1}$ \\ ${ }^{1}$ Department of Biochemistry, University of Nijmegen, P.0. Box 9101, NL-6500 \\ HB Nijmegen, The Netherlands \\ 2 Department of Medicine, Division of Rheumatology, Immunology, and Allergy, \\ Brigham \& Women's Hospital, Boston, Massuchusetts, MA 02115, USA \\ * Corresponding author: WGJ Degen, Department of Biochemistry, University \\ of Nijmegen, P.0. Box 9101, NL-6500 HB Nijmegen, The Netherlands. \\ Tel: (+31) 24361 4253; Fax: (+31) 24354 0525; \\ E-mail: w.degen@bioch.kun.nl
}

Received 2.6.99; revised 10.9.99; accepted 19.10 .99

Edited by A Strasser

\begin{abstract}
During apoptosis, the U1-70K protein, a component of the spliceosomal U1 snRNP complex, is specifically cleaved by the enzyme caspase-3, converting it into a C-terminally truncated 40-kDa fragment. In this study, we show that the 40$\mathrm{kDa} \mathrm{U} 1-70 \mathrm{~K}$ fragment is still associated with the complete U1 snRNP complex, and that no obvious modifications occur with the U1 snRNP associated proteins U1A, U1C and Sm-B/B'. Furthermore, it is described for the first time that the U1 snRNA molecule, which is the backbone of the U1 snRNP complex, is modified during apoptosis by the specific removal of the first 5-6 nucleotides including the 2,2,7-trimethylguanosine (TMG) cap. The observations that U1 snRNA cleavage is very specific (no such modifications were detected for the other $U$ snRNAs tested) and that U1 snRNA cleavage is markedly inhibited in the presence of caspase inhibitors, indicate that an apoptotically activated ribonuclease is responsible for the specific modification of U1 snRNA during apoptosis. Cell Death and Differentiation (2000) 7, 70-79.
\end{abstract}

Keywords: U1 snRNP; U1-70K; U1 snRNA; apoptosis; caspase

\footnotetext{
Abbreviations: Ac, acetyl; CMK, chloromethylketone; DMSO, dimethyl sulfoxide; DTE, dithioerythritol; FasL, Fas-Ligand; FCS, fetal calf serum; FITC, fluorescein isothiocyanate; FMK, fluoromethylketone; mAb, monoclonal antibody; NP-40, nonidet P-40; nt, nucleotide; PAGE, polyacrylamide gel electrophoresis; PBS, phosphate buffered saline; $\mathrm{PI}$, propidium iodide; $\Psi$, pseudouridine; ScFv, single chain variable fragment; SDS, sodium dodecyl sulfate; SLE, systemic lupus erythematosus; snRNP, small nuclear ribonucleoprotein; SR protein/domain, serine-arginine rich protein/ domain; TMG, 2,2,7-trimethylguanosine; Z, benzyloxycarbonyl
}

\section{Introduction}

The U1 small nuclear ribonucleoprotein (U1 snRNP) complex is a common target for autoantibodies present in the serum of patients with systemic lupus erythematosus (SLE) and SLEoverlap syndromes. ${ }^{1,2}$ The U1 snRNP complex contains the U1 snRNA molecule and the U1 snRNP specific proteins U1$70 \mathrm{~K}, \mathrm{U} 1 \mathrm{~A}$, and U1C plus a common set of eight proteins, called the Sm proteins. Most of these individual components, including the U1 snRNA, ${ }^{3-5}$ have been shown to be a target of patient autoantibodies (reviewed by Klein Gunnewiek et al.). ${ }^{6}$

The mechanisms by which these components of the U1 snRNP complex and other autoantigens escape immunological tolerance are largely unknown, although a number of recent observations suggest that modified self-proteins that are generated during apoptosis (i.e. programmed cell death) ${ }^{7}$ or necrosis, ${ }^{8}$ may play an important role in the development of autoimmunity. It has been shown that autoantigens targeted in SLE become concentrated in two discrete populations of surface structures on apoptotic cells, namely apoptotic bodies and apoptotic surface blebs. ${ }^{9-11}$ At present, the apoptotic cleavage of many of these autoantigens by caspases, a family of cysteinyl aspartate-specific proteinases, ${ }^{12}$ has been documented (reviewed in Utz and Anderson). ${ }^{13}$ Since most of these autoantigens have important functions in the cell, their cleavage during early stages of apoptosis may be expected to silence basic cellular processes.

For example, the U1 snRNP complex is involved in premRNA splicing ${ }^{14}$ and the U1-70K protein plays an essential role in this process. ${ }^{15}$ During apoptosis, the U1-70K protein is specifically cleaved by the enzyme caspase- 3 , converting it into a C-terminally truncated $40-\mathrm{kDa}$ protein. ${ }^{16,17}$ It is possible that the loss of the C-terminus, which contains an SR-domain known to be important for its interaction with other splicing factors, ${ }^{6}$ renders the U1-70K protein nonfunctional, thus abrogating the process of mRNA splicing. It is currently unknown whether this $40-\mathrm{kDa}$ cleavage product is still associated with the U1 snRNP complex in apoptotic cells.

In addition to caspase cleavage, other modifications of autoantigens have been described. It has been shown recently that at least four hyperphosphorylated SR proteins, i.e. pp54, pp42, pp34, and pp23, become associated with the apoptotic U1 snRNP complex. ${ }^{18}$ As discussed in detail elsewhere, the altered localization of the U1 snRNP complex in apoptotic cells, together with modifications of the complex during cell death (i.e. caspase-mediated cleavage of U1-70K and the association with hyperphosphorylated SR proteins) may be critical determinants in the development of an immune response to the U1 snRNP complex in susceptible individuals. ${ }^{13}$ In this context it 
should be noted that the U1 snRNA molecule is also a major target of autoimmunity in SLE-overlap syndromes, ${ }^{1,2}$ and that changes in the titer of anti-U1 snRNA autoantibodies appear to correlate with the severity of the disease. ${ }^{5}$ Therefore, it would be interesting to investigate whether the U1 snRNA molecule is also modified during apoptosis.

In this study, we have analyzed the fate of the U1 snRNP complex during Fas-induced apoptosis of Jurkat cells. We show that the U1 snRNA molecule is modified by the specific loss of the first 5-6 nucleotides including the 2,2,7-trimethylguanosine-cap (TMG) during anti-Fas induced apoptosis. Furthermore, it is shown that the 40$\mathrm{kDa}$ apoptotic fragment of the $\mathrm{U} 1-70 \mathrm{~K}$ protein remains associated with the U1 snRNP complex, and that the U1A, $\mathrm{U} 1 \mathrm{C}$ and $\mathrm{Sm}-\mathrm{B} / \mathrm{B}^{\prime}$ proteins remain associated as well, but are not detectably modified.

\section{Results}

The extent of anti-Fas (mAb 7C11) induced apoptosis in Jurkat cells was assessed by flow cytometry using annexin $\mathrm{V}$ FITC and propidium iodide (Figure 1). Annexin $V$ stains phosphatidylserine, a marker for the early apoptotic state, ${ }^{19}$ whereas staining with propidium iodide is indicative for a late state of apoptosis (secondary necrosis). Using annexin V staining it was established that $57.1 \%$ of the Jurkat/control cells were apoptotic $2 \mathrm{~h}$ after addition of the anti-Fas antibody, while this percentage increased to $79.3 \%$ after $4 \mathrm{~h}$, and $90.3 \%$ after $8 \mathrm{~h}$. At the latter time point only $9.1 \%$ of the Jurkat/control cells were permeable to propidium iodide.

\section{The 40-kDa protein fragment of U1-70K remains associated with the U1 snRNP complex in apoptotic cells}

During apoptosis, the U1-70K protein is specifically cleaved by the enzyme caspase-3, converting it into a C-terminally truncated $40-\mathrm{kDa}$ protein. ${ }^{16,17}$ For the detection of both U1$70 \mathrm{~K}$ and the $40-\mathrm{kDa}$ protein fragment in non-apoptotic and apoptotic cell lysates we routinely used an SLE patient serum (i.e. H42) containing polyclonal antibodies directed to the U1$70 \mathrm{~K}$ protein. The characteristic apoptotic $40-\mathrm{kDa}$ cleavage product was already detectable $2 \mathrm{~h}$ after anti-Fas $\mathrm{mAb}$ addition in Jurkat/control cells, and gradually increased to a maximum level at $8 \mathrm{~h}$. At the latter time point hardly any uncleaved U1-70K was detectable (Figure 2A, left panel). In Jurkat/Bcl-2 cells, in which the apoptotic process is inhibited, ${ }^{20,21}$ only a small amount of U1-70K was cleaved (Figure 2A, right panel).

To investigate whether the $40-\mathrm{kDa}$ cleavage product remains associated with the U1 snRNP complex in apoptotic cells, we immunoprecipitated U1 snRNP complexes derived from non-apoptotic and apoptotic cells using monoclonal antibodies directed to the U1 snRNP specific proteins U1A (mAb 9A9, which also recognizes U2B") 22 and U1C (scFv K36), ${ }^{23}$ and to the common or Sm-proteins Sm-D1 (mAb KSm2) ${ }^{24}$ and Sm-B/B' (mAb KSm5). ${ }^{24}$ Immunoprecipitates were then analyzed by immunoblotting using the anti-U1-70K serum H42 (Figure 2B). In all cases the $40-\mathrm{kDa}$ cleavage product was found in the immunoprecipitate of apoptotic Jurkat/control cell lysates indicating that the $40-\mathrm{kDa}$ protein fragment (as well as the U1A, U1C, Sm-D1 and Sm-B/B' proteins) is still associated with the U1 snRNP complex in apoptotic cells. Note that probably due to antibody titer differences the efficiencies of immunoprecipitations by the various antibodies showed some variation. Interestingly, the data obtained with the very efficiently precipitating anti-Sm-B/B' antibody indicate that there is essentially no release of the $40-\mathrm{kDa}$ fragment from the complex (Figure 2B, lanes 13-16). Electrophoretic separation in two dimensions of immunoprecipitated apoptotic U1 snRNP complexes confirmed that the 40$\mathrm{kDa}$ cleavage product and phosphorylated SR proteins are associated with the U1 snRNP complex during Fas-induced apoptosis ( ${ }^{18}$ and results not shown).

As reported before by Casiano et al. ${ }^{25}$ we also found that the $\mathrm{U} 1 \mathrm{~A}, \mathrm{U} 1 \mathrm{C}$, and $\mathrm{Sm}-\mathrm{B} / \mathrm{B}^{\prime}$ proteins were not detectably cleaved during anti-Fas induced apoptosis (Figure 2C).

\section{The U1 snRNA molecule is cleaved during anti-Fas induced apoptosis}

The results presented above strongly suggest that the Fasmediated apoptotic cleavage of the U1-70K protein takes
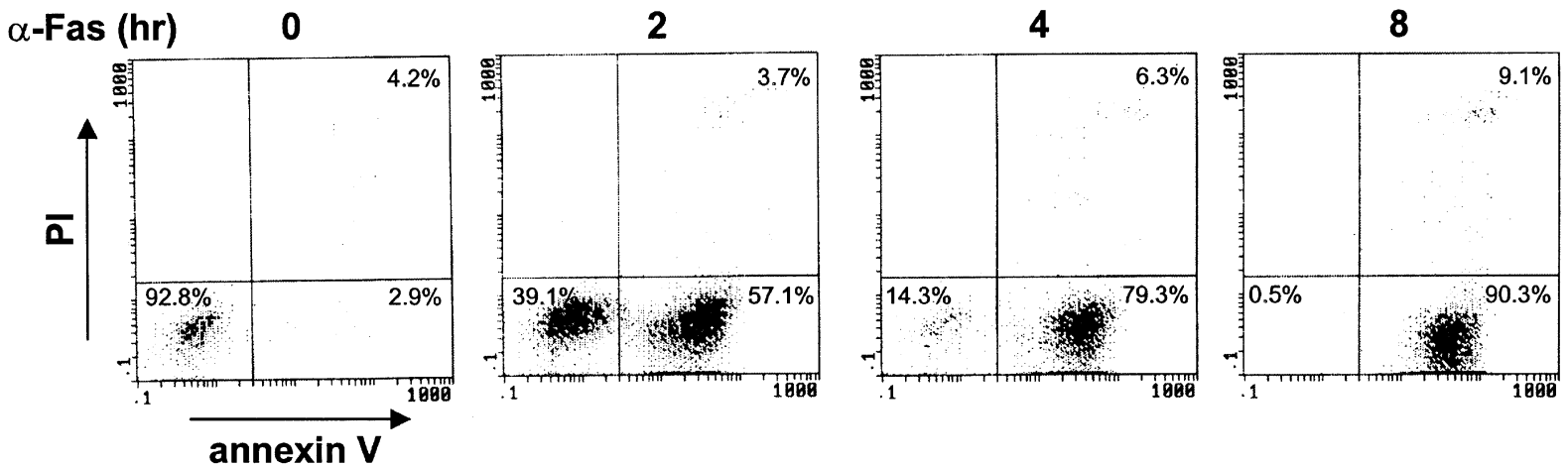

Figure 1 Induction of Fas mediated apoptosis in Jurkat/control cells by treatment with the monoclonal anti-Fas antibody $7 \mathrm{C} 11$ monitored by flow cytometry. PI, propidium iodide 
place within the intact U1 snRNP complex. Since it was unclear how the U1 snRNA itself behaved during apoptosis, we performed additional experiments aimed at elucidating this issue. The behavior of the U1 snRNA molecule during antiFas induced apoptosis was examined by Northern blotting. Total RNA of Jurkat cells (Jurkat/control, Jurkat/Bcl-2) was isolated at various time points after the addition of anti-Fas antibody and subsequently analyzed by Northern blotting using an U1 snRNA specific probe. The results demonstrated the appearance of a somewhat faster migrating, truncated RNA species during apoptosis, which efficiently hybridized with the U1 snRNA specific probe, concomitant with a slight

A

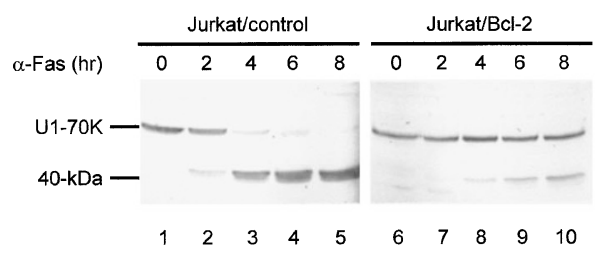

B

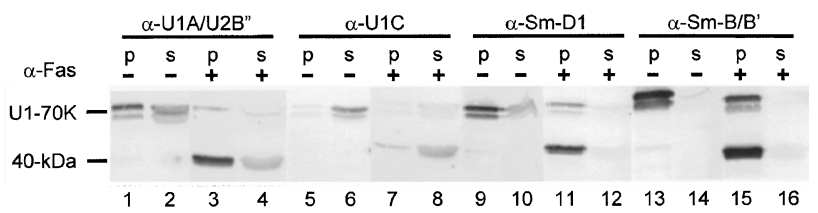

C

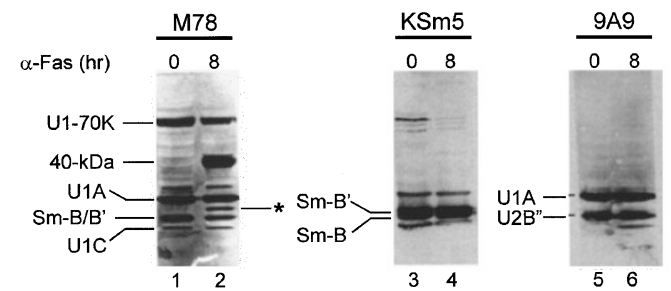

Figure 2 Cleavage of the U1-70K protein during anti-Fas induced apoptosis (A) Jurkat/control and Jurkat/Bcl-2 cells were treated with the anti-Fas $\mathrm{mAb}$ $7 \mathrm{C} 11$ for the indicated time periods. Protein extracts were analyzed by $10 \%$ SDS-PAGE and Western blotting using an anti-U1-70K patient serum (H42). (B) The $40-\mathrm{kDa}$ protein fragment of U1-70K remains associated with the U1 snRNP complex. U1 snRNP complexes were immunoprecipitated from nonapoptotic (,$- 0 \mathrm{~h}$. anti-Fas $\mathrm{mAb})$ and apoptotic $(+, 8 \mathrm{~h}$. anti-Fas $\mathrm{mAb})$ Jurkat/ control cell extracts using anti-U1A/U2B" ( $\alpha$-U1A/U2B", mAb 9A9), anti-U1C $(\alpha-\mathrm{U} 1 \mathrm{C}, \mathrm{scFv} \mathrm{K} 36)$, anti-Sm-D1 ( $\alpha$-Sm-D1, mAb KSm2) and anti-Sm-B/B' $(\alpha-$ $\left.\mathrm{Sm}-\mathrm{B} / \mathrm{B}^{\prime}, \mathrm{mAb} \mathrm{KSm5}\right)$ monoclonal antibodies. Immunoprecipitates ( $\left.p\right)$ and supernatants (s) were analyzed by $10 \%$ SDS-PAGE and Western blotting using an anti-U1-70K patient serum (H42). The positions of U1-70K and its 40 $\mathrm{kDa}$ cleavage product are indicated on the left. (C) U1 snRNP specific proteins are not detectably modified by cleavage. Jurkat/control cells were treated with anti-Fas $\mathrm{mAb}$ for the indicated time periods. Protein extracts were analyzed by $10 \%$ SDS - PAGE and Western blotting using anti-U1-70K/anti-U1A/anti-U1C/ anti-Sm-B/B' patient serum (M78), and the anti-Sm-B/B' (mAb KSm5) and antiU1A/U2B" (mAb 9A9) monoclonal antibodies. *C-terminal fragment of U1-70K after apoptotic cleavage decrease in the full-length U1 snRNA signal (Figure 3A, left panel). The analysis of this material on higher resolution gels (see also below) revealed that the truncated U1 snRNA species migrated as a doublet suggesting that the U1 snRNA is cleaved at two closely spaced sites. The first appearance of both shortened U1 snRNA products coincided with the first appearance of the $40-\mathrm{kDa}$ cleavage product of the U1-70K protein, approximately between 2 and $4 \mathrm{~h}$ after the addition of anti-Fas antibodies (compare the left panels of Figure 2A, Figure $3 \mathrm{~A}$ and Figure $6 \mathrm{~A}$ ). Quantitative measurements indicated that approximately $20-25 \%$ of the U1 snRNA molecules was cleaved $8 \mathrm{~h}$ after the induction of apoptosis in Jurkat/control cells. To confirm that cleavage of the U1 snRNA molecule in Jurkat cells incubated with the anti-Fas antibody was Fas receptor mediated, we also treated Jurkat/control cells with murine Fas-Ligand (FasL). As shown before with the anti-Fas antibody, the U1 snRNA molecule and the U1-70K protein were cleaved when FasL containing supernatant was used to induce apoptosis (Figure 3B). The cleavage products generated in both apoptotic scenarios appeared to be identical. Consistent with the retarded induction of apoptosis in the Jurkat/Bcl-2 cell line, the faster migrating U1 snRNA molecules appeared later and in smaller amounts (Figure $3 \mathrm{~A}$, right panel). The specificity of apoptotic U1 snRNA cleavage was substantiated by the lack of detectable changes in electrophoretic mobilities and quantities of U2, U3, U4, U5, and $U 6$ snRNAs during the time period of apoptosis studied (Figure 3C).

Antibodies directed to several other snRNP components, such as U1A (mAb 9A9), U1-70K (mAb 2.73) and Sm-B/B', Sm-D1 and Sm-D3 (mAb Y12), immunoprecipitated both human U1 snRNA and its two cleavage products, indicating that these U1 snRNP-associated proteins remain associated with intact and cleaved U1 snRNA (results not shown).

\section{Apoptotic cleavage of U1 snRNA is sensitive to caspase inhibition}

It has been reported that in normal lymphocytes Bcl-2 does not inhibit Fas induced apoptosis ${ }^{26}$ and that Bcl-2 can have different effects on cell death in the same cell depending on the apoptotic stimulus. ${ }^{27}$ In the Bcl-2 overexpressing Jurkat transfectant tested in our experiments apoptosis was markedly inhibited (see Figure 2A and Figure 3A). To exclude an apoptosis inhibiting behavior specific for this particular transfectant, and to determine whether caspase activation is required to induce apoptotic cleavage of U1 snRNA (see Figure $3 A$ ), Jurkat/control cells were cultured in the presence of four cell permeable tetrapeptide caspase inhibitors, Ac-YVADCMK, Z-DEVD-FMK, Z-IETD-FMK, or Z-LEHD-FMK (irreversible inhibitors of caspases 1, 3, 8 and 9, respectively), for $1 \mathrm{~h}$ at $37^{\circ} \mathrm{C}$ prior to incubation with anti-Fas antibodies for an additional $8 \mathrm{~h}$. The cleavage of U1 snRNA was markedly inhibited with the caspase-1, -3 , and -8 inhibitors at $20 \mu \mathrm{M}$ (Figure 4, lanes 3-8, lower panel) as compared to the control (lane 2), whereas hardly any inhibition of U1 snRNA cleavage was observed in the presence of the caspase- 9 inhibitor (Figure 4, lanes 9 and 10, lower panel). All caspase inhibitors tested inhibited the U1-70K cleavage (Figure 4, lanes 3-10, 
A

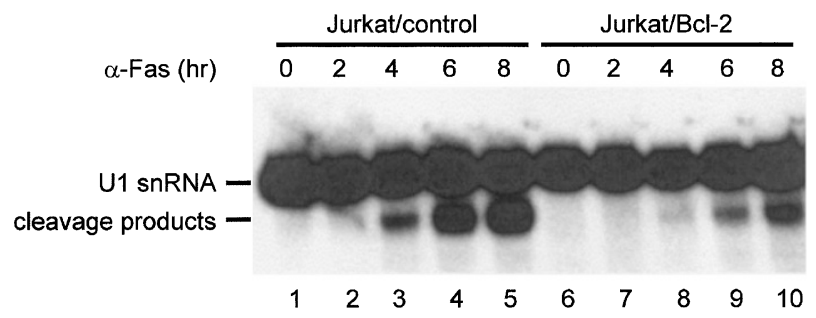

B

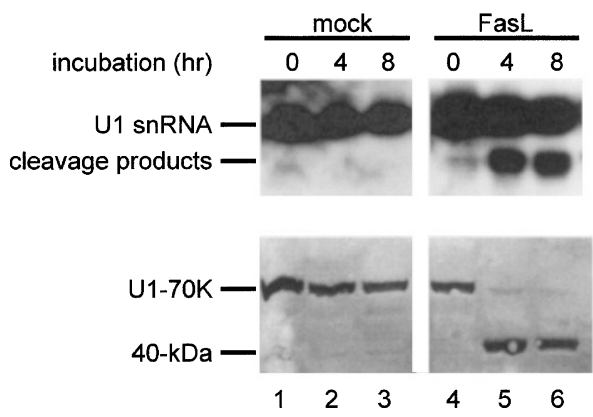

\section{C}
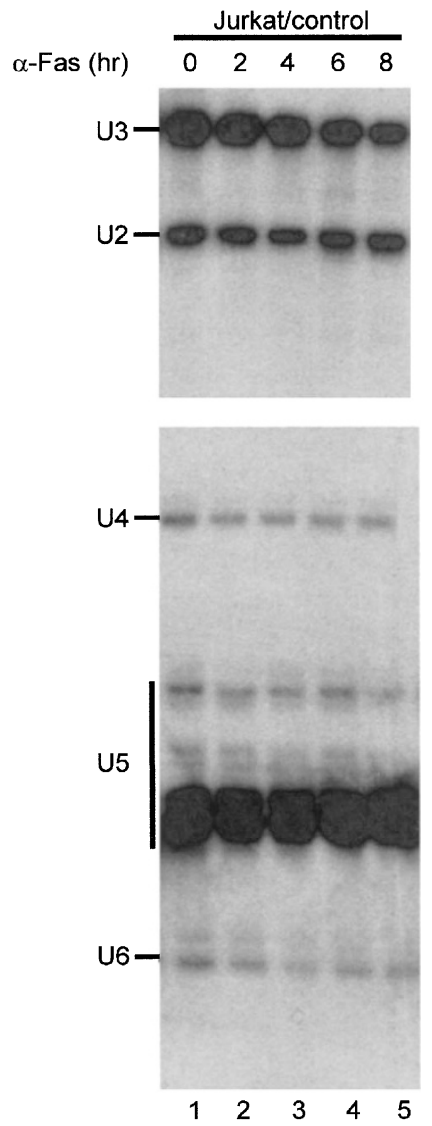

Figure 3 Cleavage of U1 snRNA during anti-Fas induced apoptosis. (A) The U1 snRNA molecule is cleaved during anti-Fas induced apoptosis. Jurkat cells were treated with the anti-Fas $\mathrm{mAb} 7 \mathrm{C} 11$ for the indicated time periods. Total upper panel), although the inhibitory activity of the caspase-9 inhibitor was not as strong as that of the other inhibitors.

\section{The U1 snRNA molecule is cleaved in other apoptotic cells}

To investigate whether U1 snRNA cleavage in apoptotic cells is a universal phenomenon, we analyzed U1 snRNA by Northern blot hybridization in various other apoptotic cells and after the induction of apoptosis with different stimuli. The results show that the U1 snRNA molecule is cleaved in human HL-60 (promyelocytic leukemia) and in mouse 4B1 cells (WR19L cells overexpressing the human Fas-receptor) ${ }^{28}$ treated with the anti-Fas antibody $7 \mathrm{C} 11$ (Figure 5, lanes 1-5), in Jurkat/control cells treated with staurosporine, cycloheximide or anisomycin (Figure 5, lanes 6-9), and in human HeLa (cervix carcinoma) and HL-60 cells treated with anisomycin (Figure 5, lanes 10-13). From these experiments it can be concluded that the cleavage of the U1 snRNA molecule is a general feature of the degeneration process in the apoptotic cell.

\section{Apoptotically cleaved U1 snRNA lacks a 2,2,7- trimethylguanosine (TMG) cap}

To analyze which part of the U1 snRNA molecule is removed during anti-Fas induced apoptosis, immunoprecipitations were carried out using monoclonal antibodies directed to the 2,2,7trimethylguanosine (TMG) cap (H20) and to U1-stemloop II (Z5scFv3). ${ }^{29}$ The anti-U1-stemloop II scFv antibody immunoprecipitated the U1 snRNA as well as its cleavage products (Figure 6A, upper panel). In contrast, the anti-TMG cap antibody precipitated full-length U1 snRNA but not its cleavage products, indicating that the TMG cap was absent from the latter (Figure 6A, lower panel). Although no electrophoretic mobility changes were detected in the U2U6 snRNAs by Northern blot hybridization (Figure 3C), it could not be excluded that the TMG cap of these RNAs (except for U6 snRNA, which is not TMG capped) was also lost or changed during apoptosis. Therefore, RNAs immunoprecipitated with anti-TMG cap antibodies were analyzed by $3^{\prime}$-end labeling and denaturing gel electrophoresis. Like the full-length U1 snRNA, the U2, U3, U4 and U5 snRNAs could be precipitated with the anti-TMG cap antibody from apoptotic cell extracts, indicating that these RNAs were not de-capped (Figure 6B).

RNA was size fractionated on a $6 \%$ polyacrylamide/ $8 \mathrm{M}$ urea sequencing gel and analyzed by Northern blot hybridization using a ${ }^{32} \mathrm{P}$-labeled antisense U1 RNA probe. The positions of full-length U1 snRNA and its cleavage products are indicated on the left. (B) The U1 snRNA molecule is cleaved during FasL induced apoptosis. Jurkat/control cells were treated with murine FasL for the indicated time periods and total RNA was analyzed by Northern blot hybridization as described in A. Total protein extracts were analyzed by $10 \%$ SDS-PAGE and Western blotting using an anti-U1-70K patient serum (lower panel). The positions of U1 snRNA and its cleavage products as well as U1-70K and its 40-kDa cleavage product are indicated on the left. (C) The U2, U3, U4, U5 and U6 snRNAs are not cleaved during anti-Fas induced apoptosis. Total RNA from Jurkat/control cells treated with the anti-Fas mAb 7C11 for the indicated time periods was analyzed by Northern blot hybridization as described in A using ${ }^{32} \mathrm{P}$-labeled antisense $U$ RNA probes as indicated on the left 


\section{Mapping of the apoptotic U1 snRNA cleavage site}

Based on the finding that the cleaved U1 snRNA could not be precipitated via anti-TMG cap antibodies, S1 nuclease mapping was used to determine the identity of the $5^{\prime}$ end(s) of the cleaved U1 snRNA. A 49 nucleotides long 5'end ${ }^{32} \mathrm{P}$-labeled oligonucleotide complementary to the $5^{\prime}$ end of the wild type (native) U1 snRNA was incubated overnight with deproteinized total RNA from Jurkat/control and apoptotic cells, followed by digestion with S1 nuclease. The first (5') 39 nucleotides of this oligonucleotide are complementary to the 5 '-end of the wild type U1 snRNA molecule, whereas a stretch of ten A-residues completed the oligonucleotide at the $3^{\prime}$-end (Figure 7A). Posttranscriptional modifications in the most $5^{\prime}$-end of the native U1 snRNA molecule (i.e. a 2,2,7-trimethylguanosine (TMG) cap, a 2'-O-methylated adenosine and uridine, and two pseudouridines $(\Psi)$, appeared to destabilize the DNARNA hybrid. As a consequence, the region of the probe corresponding to the terminal region of native U1 snRNA was more sensitive to $S 1$ nuclease digestion resulting in several (minor) nuclease protection products in addition to

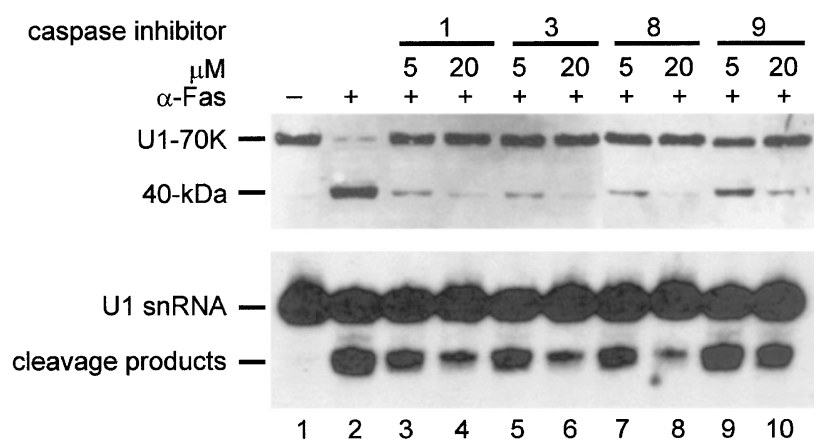

Figure 4 Apoptotic cleavage of U1 snRNA is sensitive to caspase inhibition Jurkat/control cells were incubated with four cell permeable tetrapeptide caspase inhibitors, $5 \mu \mathrm{M}$ (lanes $3,5,7,9$ ) or $20 \mu \mathrm{M}$ (lanes $4,6,8,10$ ) of caspase-1, $-3,-8$ and -9 inhibitors, for $1 \mathrm{~h}$ at $37^{\circ} \mathrm{C}$ prior to incubation with antiFas antibodies for an additional $8 \mathrm{~h}(+)$. Total protein extracts were analyzed by $10 \%$ SDS - PAGE and Western blotting using an anti-U1-70K patient serum (upper panel). Total RNA was analyzed by Northern blot hybridization using a ${ }^{32} \mathrm{P}$-labeled antisense U1 RNA probe (lower panel). In lanes 1 and 2 material from non-apoptotic $(-, 0 \mathrm{~h}$. anti-Fas $\mathrm{mAb})$ and apoptotic $(+, 8 \mathrm{~h}$. anti-Fas $\mathrm{mAb})$ cells, respectively, was analyzed. The positions of U1-70K and its $40-\mathrm{kDa}$ cleavage product as well as U1 snRNA and its cleavage products are indicated on the left

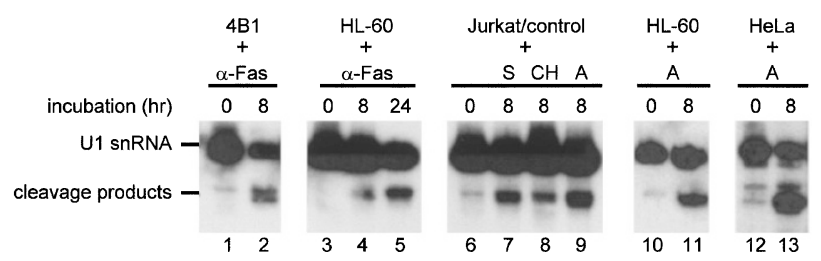

Figure 5 The U1 snRNA molecule is cleaved in various apoptotic cells treated with different apoptotic stimuli. Cells were treated with anti-Fas $\mathrm{mAb}$ $7 C 11$, staurosporine $(S)$, cycloheximide $(C)$ or anisomycin $(A)$ for the indicated time periods. Total RNA was isolated and analyzed by Northern blot hybridization using a ${ }^{32} \mathrm{P}$-labeled antisense U1 RNA probe. The positions of full-length U1 snRNA and its cleavage products are indicated on the left products corresponding to the 5 '-ends of intact (39 nt) and cleaved U1 snRNA ( $<39 \mathrm{nt}$ ) (Figure 7B, lanes 1 and 2 ). The precise lengths of the various $\mathrm{S} 1$ protected oligonucleotide fragments were determined using 5 '-end ${ }^{32} \mathrm{P}$-labeled oligonucleotides as marker. The longest S1 protected oligonucleotide contains 40 nucleotides (Figure $7 \mathrm{~B}$, lanes 1 and 2) and corresponds to the S1 protected 5'end of the complete U1 snRNA (39 nt) plus the first flanking A-residue $\left(A_{40}\right)$. The inability of $S 1$ nuclease to remove $A_{40}$ efficiently is probably the result of steric effects by and possibly unusual base-paring with the 2,2,7trimethylguanosine cap of intact $\mathrm{U} 1$ snRNA. The S1 protected oligonucleotide fragments of 33 and 34 nucleotides resulting from U1 snRNA immunoprecipitated from apoptotic cell extracts (Figure 7B, lane 2) were much more intense than the corresponding fragments resulting from non-apoptotic RNA (Figure 7B, lane 1). This strongly suggested that these protected oligonucleotide fragments corresponded to the 5 -ends of the apoptotically cleaved U1 snRNA molecules. This was confirmed in an experiment in which full-length and cleaved U1 snRNA were gel purified (6\% polyacrylamide/8 M urea) and independently analyzed by nuclease protection. The 33 and 34 nucleotides long S1 protected oligonucleotide fragments indeed correspond to the 5 '-ends of the cleaved U1 snRNA molecules (Figure 7B, lanes 3 and 4). Thus the results of the $\mathrm{S} 1$ mapping experiment indicate that the $\mathrm{U} 1$ snRNA molecule is cleaved either between nucleotides C5 and $\Psi 6$, or between nucleotides $\Psi 6$ and $\Psi 7$.

\section{Discussion}

During the last 5 years there has been a growing interest in finding possible connections between apoptosis and the induction of autoimmunity. At present, many autoantigens have been found that are modified during apoptosis, ${ }^{13}$ and it has been hypothesized that the recognition, uptake, processing, or presentation of these modified self-antigens may promote autoantibody production.

One of these autoantigens is the $\mathrm{U} 1-70 \mathrm{~K}$ protein, a component of the U1 small nuclear ribonucleoprotein (U1 snRNP) complex. This protein (437 aa) ${ }^{30}$ has an important function in the pre-mRNA splicing reaction as it enhances the interaction of the U1 snRNP complex with the $5^{\prime}$ splice site. In 1994, Casciola-Rosen and collaborators ${ }^{16}$ reported that the $\mathrm{U} 1-70 \mathrm{~K}$ protein was specifically cleaved during apoptosis, and they subsequently demonstrated that the U1-70K protein was cleaved at position ${ }^{338}{ }^{2 G P D}{ }^{341}$ by caspase-3 (CPP32, Apopain, Yama), resulting in an $\mathrm{N}$ terminal $40-\mathrm{kDa}$ (aa 1-341) and a C-terminal 22-kDa (aa $342-437$ ) protein fragment. ${ }^{17}$ By analyzing the U1 snRNP complex during anti-Fas induced apoptosis, we demonstrated that it is likely that the U1-70K protein is cleaved while it is associated with the intact U1 snRNP complex in apoptotic cells, and that the N-terminal $40-\mathrm{kDa}$ fragment remains associated with the U1 snRNP complex. The latter finding is consistent with the location of the RNA-binding domain (RBD, aa region $104-184$ ) in the N-terminal half of the molecule, which has been shown previously to be sufficient for U1 snRNP association. ${ }^{31}$ No obvious apoptotic 
A
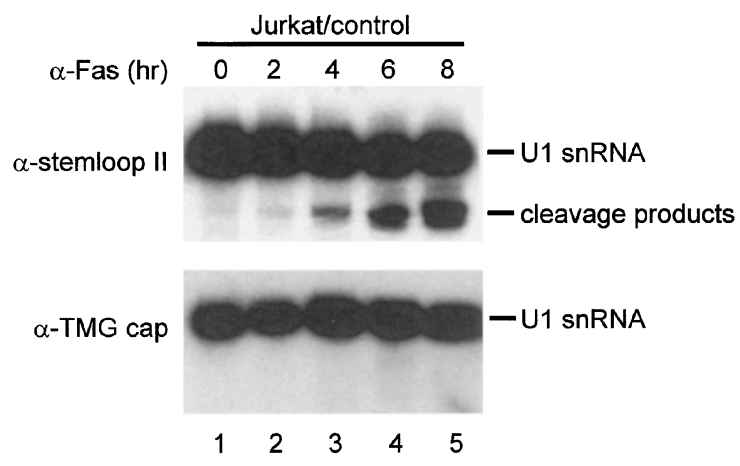

B

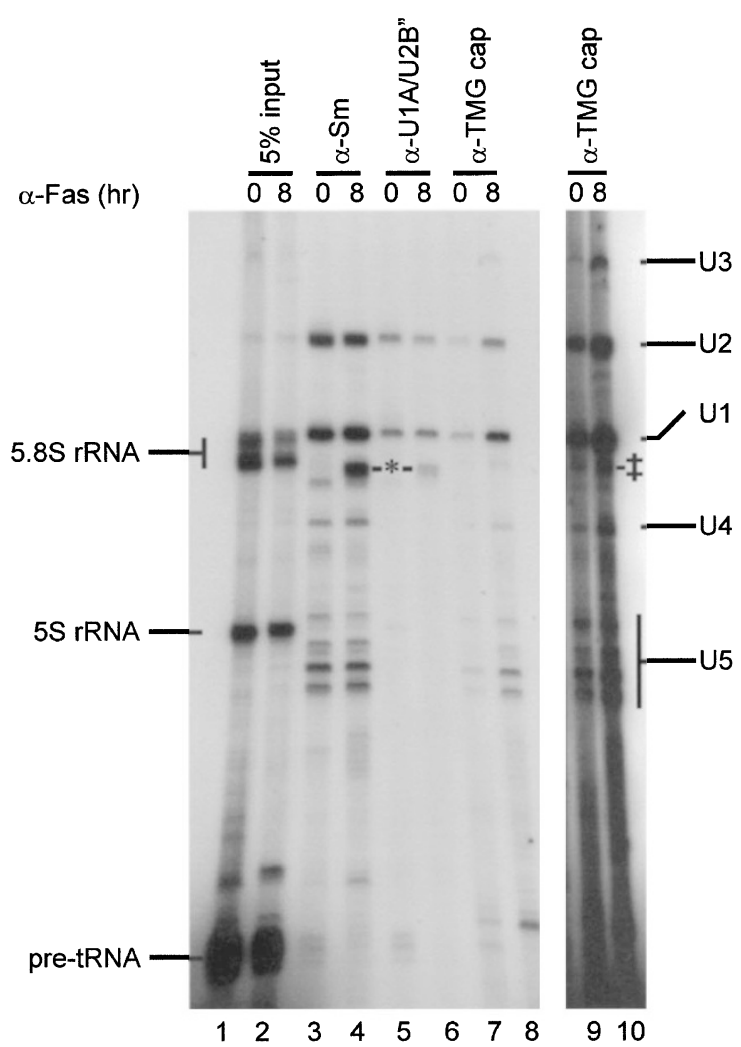

Figure 6 The U1 snRNA molecule loses its TMG cap structure during antiFas induced apoptosis. (A) Apoptotically cleaved U1 snRNA can not be precipitated with anti-TMG cap antibodies. Jurkat cells were treated with the anti-Fas $\mathrm{mAb} 7 \mathrm{C} 11$ for the indicated time periods. U1 snRNP complexes were immunoprecipitated from cell extracts using anti-stemloop II (scFv Z5scFv3, upper panel) and anti-TMG cap (mAb H20, lower panel) antibodies. Immunoprecipitated RNA was size fractionated on a $6 \%$ polyacrylamide/8 $\mathrm{M}$ urea sequencing gel and analyzed by Northern blot hybridization using a ${ }^{32} \mathrm{P}$ labeled antisense U1 RNA probe. The positions of full-length U1 snRNA and its cleavage products are indicated on the right. (B) The U2, U3, U4 and U5 snRNAs remain TMG capped during apoptosis. U snRNP complexes were immunoprecipitated from non-apoptotic $(0 \mathrm{~h}$. anti-Fas $m A b)$ and apoptotic $(8 \mathrm{~h}$. anti-Fas $m A b)$ Jurkat/control cell extracts using anti-Sm ( $\alpha-S m, m A b$ Y12), anti-U1A/U2B" ( $\alpha$-U1A/U2B"', mAb 9A9), and anti-TMG cap ( $\alpha$-TMG cap, mAb $\mathrm{H} 20$ ) antibodies. Immunoprecipitated RNA was ${ }^{32} \mathrm{P}-\mathrm{pCp}$ labeled, size fractionated on a $10 \%$ polyacrylamide/ $8 \mathrm{M}$ urea sequencing gel and visualized by autoradiography. Lanes 9 and 10 show an overexposure of lanes 7 and 8 . The positions of the most abundant RNAs in the cell extracts (input, lanes 1 changes were detected in the U1 snRNP associated proteins $\mathrm{U} 1 \mathrm{~A}, \mathrm{U} 1 \mathrm{C}$, and the Sm-proteins $\mathrm{B} / \mathrm{B}^{\prime}\left(^{25}\right.$ and Figure 2C).

The major finding of the present study is that the $U 1$ snRNA molecule is specifically cleaved in apoptotic mammalian and mouse cells, either between nucleotides C5 and $\Psi 6$ or between nucleotides $\Psi 6$ and $\Psi 7$, resulting in

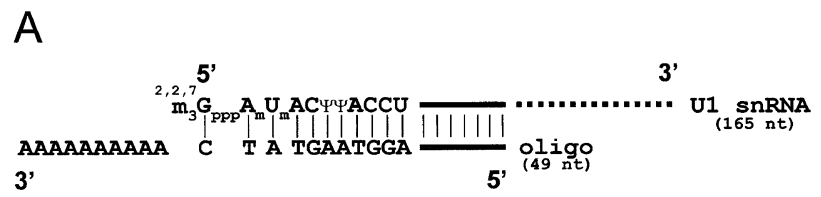

B

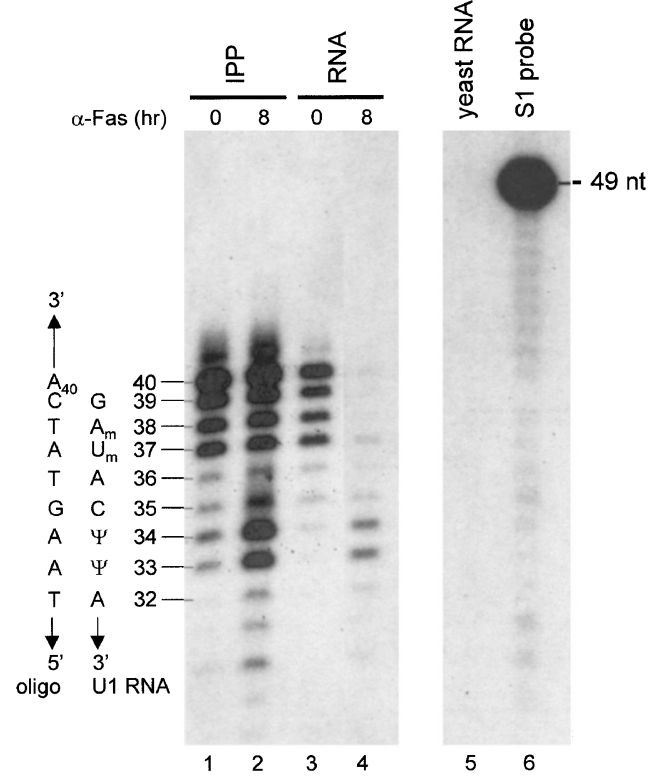

Figure 7 S1 nuclease mapping of the apoptotic U1 snRNA cleavage site(s). (A) Schematic structure of the 5 -end of U1 snRNA hybridizing with the 49 nucleotides long oligonucleotide that was used as a probe for nuclease protection. Note the presence of the TMG cap, methylated riboses at positions 2 and 3 and pseudouridines $(\Psi)$ at positions 6 and 7 in the $5^{\prime}$-terminal region of native U1 snRNA. (B) Nuclease S1 protection data for apoptotic U1 snRNA. The 49 nucleotides long ${ }^{32} \mathrm{P}$-labeled oligonucleotide complementary to the $5^{\prime}$ end of the U1 snRNA molecule was hybridized with RNA from non-apoptotic $(0 \mathrm{~h}$. anti-Fas $\mathrm{mAb}$ ) or apoptotic ( $8 \mathrm{~h}$. anti-Fas $\mathrm{mAb})$ Jurkat/control cells (equivalent of $5 \times 10^{6}$ cells), or with yeast RNA (as a control). Upon treatment with nuclease $\mathrm{S} 1$, the reaction products were analyzed by denaturing gel electrophoresis. Lane 1, immunoprecipitated non-apoptotic U1 snRNA; lane 2, immunoprecipitated apoptotic U1 snRNA; lane 3, gel purified native U1 snRNA; lane 4, gel purified apoptotically cleaved U1 snRNA; lane 5, yeast RNA at $37^{\circ} \mathrm{C}$ (as a control); lane 6 , the 49 nucleotides long undigested ${ }^{32} \mathrm{P}$ labeled oligonucleotide. The immunoprecipitations were performed with the anti-U1A/U2B" monoclonal antibody 9A9. On the left the size of the protected fragments is indicated, as well as the corresponding nucleotides of both the oligonucleotide probe and U1 snRNA

and 2) and of the $U$ snRNAs are indicated on the left and on the right, respectively. *Apoptotic cleavage products of U1 snRNA. †Degradation products of U1 snRNA only seen after overexposure 
two truncated apoptotic RNA molecules each starting with a pseudouridine $(\Psi)$. These results might suggest that pseudouridines are involved in the selection of cleavage sites for the apoptotically activated nuclease responsible for U1 snRNA cleavage. However, the mere presence of $\Psi$ residues in single-stranded regions of RNAs does not seem to be sufficient for cleavage, since the U2, U3, U4, U5, and U6 snRNAs are not cleaved despite the presence of numerous $\Psi$-residues. ${ }^{32,33}$ Also the presence of two consecutive $\Psi$-residues, which occur at the cleavage sites of U1 snRNA, does not seem to constitute the cleavage determinant, because such a $\Psi$-doublet also occurs in a single-stranded region near the 5 '-end (nucleotides 7 and 8) of the U2 snRNA molecule, which apparently is not cleaved at this position. Taken together, while at least one pseudouridine (in a single-stranded region) might be required for recognition by the putative apoptotically activated RNase, other structural elements seem to be necessary for cleavage to occur. Identification and characterization of the involved ribonuclease will be required to learn more about the substrate specificity of this enzyme. The U1 snRNA molecule is the first small RNA with a known cellular function reported to be cleaved during apoptosis. So far, only the cleavage of two ribosomal RNAs, i.e. the $16 \mathrm{~S}$ mitochondrial rRNA and the 28S rRNA, have been reported. ${ }^{34,35}$ Mapping of the apoptotic 16S mitochondrial rRNA cleavage sites has not been performed, but in view of our data it would be interesting to investigate whether in these cases $\Psi$ residues are also involved. For the $28 S$ rRNA, fine mapping has been performed, but $\Psi$-residues seemed not to be involved. ${ }^{36}$ Furthermore, we recently observed that the Ro RNP associated Y RNAs, the biological function of which is unknown, are rapidly degraded in apoptotic cells. ${ }^{37}$

The post-transcriptional modifications of $U$ into $\Psi$ observed at highly conserved positions in snRNAs and also other RNAs, like tRNAs and rRNAs, are in the $U$ snRNAs mainly found in single-stranded segments involved in RNA-RNA interactions. ${ }^{38-40}$ Although the function of $\Psi$ residues in $\mathrm{U}$ snRNAs remains unknown, in $\mathrm{U} 1, \mathrm{U} 2$, and U5 snRNA, these $\Psi$ s are present in regions known to be critically important for the function of these snRNPs in premRNA splicing (for a review see ${ }^{33}$ ). Removal of the first 56 nucleotides including the TMG cap of the U1 snRNA molecule will certainly thwart pre-mRNA splicing, although data to support this are not (yet) available. Interestingly, it has been shown that oligonucleotides complementary to the first 14 nucleotides of the U1 snRNA molecule can block prespliceosome and spliceosome assembly in vitro. ${ }^{41}$ We showed that the complete cellular pool of U1-70K molecules is cleaved into the $40-\mathrm{kDa}$ fragments, whereas only a subfraction $(20-25 \%)$ of the $U 1$ snRNA molecules is cleaved $8 \mathrm{~h}$ after Fas-induced apoptosis. Due to the instability and morphological changes of apoptotic cells, it is very difficult to establish which part, cytoplasmic or nuclear, of the U1 snRNA population is cleaved during apoptosis. A subset of U1 snRNPs might be protected from nuclease cleavage, either by association with other proteins (e.g. SR proteins or other spliceosomal proteins), or by sequestration in a separate cellular compartment, that is inaccessible for the nuclease. Most probably, only the U1 snRNA of non-spliceosomal free U1 snRNP is cleaved.

One of the most important biochemical events after the induction of apoptosis is the activation of the caspase cascade. Although the exact order of caspase activation is not known yet, it has been established that activation of caspase-3 can be induced via the activation of several other caspases, including caspase-1, -8, and 9. Inhibition of Fas-induced apoptosis with caspase-1, $-3,-8$, or 9 inhibitors, showed that the U1 snRNA cleavage was markedly inhibited in the presence of the caspase-1, -3 and -8 inhibitors. It should be stressed that although these tetrapeptide inhibitors display a (strong) preference for a particular caspase, their specificity is not absolute and at relatively high concentrations other caspases will also be inhibited. Therefore, the present results do not allow conclusions on the caspase that is responsible for activation of the nucleolytic activity that cleaves U1 snRNA. On the one hand the caspase inhibition data would be consistent with caspase-3 being involved in activation of this nuclease, but on the other hand the incomplete inhibition of U1 SnRNA cleavage under conditions where cleavage of a model substrate for caspase-3 (U1-70K) is virtually completely inhibited argues against this possibility. These results thus seem to indicate that the U1 snRNA molecule is cleaved by an apoptosis specific ribonuclease that is not (directly) activated by caspase-1, $-3,-8$ or 9 . The fact that this ribonuclease seems to affect only the U1 snRNA molecule and not the U2, U3, U4, U5 or U6 snRNAs is intriguing.

Autoantibodies reactive with components of the $U 1$ snRNP complex are specifically found in the sera of patients with SLE. The translocation of the U1 snRNP complex from its normal subcellular localization into apoptotic bodies near the surface of cells undergoing apoptosis, might facilitate exposure of the immune system to such antigens when clearance of apoptotic cell remnants is somehow disturbed. In combination with the apoptotic modifications of U1 snRNP components, i.e. cleavage of the U1-70K protein, association of hyperphosphorylated SR proteins, and cleavage of the U1 snRNA molecule itself, this might bypass immunological tolerance. All these structural alterations and modifications might be important for the production of autoantibodies reactive with the $\mathrm{U} 1$ snRNP complex, and support the idea of a connection between apoptosis and the emergence of autoimmunity.

\section{Materials and Methods}

\section{Cell lines}

Jurkat (human T cell leukemia) suspension cells were grown in RPMI1640 medium (Gibco-BRL) supplemented with $10 \%$ heat inactivated fetal calf serum (FCS) (Gibco-BRL), sodium-pyruvate (1 mM), penicillin $(1 \mathrm{mM})$ and streptomycin $(1 \mathrm{mM})$, and were maintained at a concentration of $1 \times 10^{6}$ cells $/ \mathrm{ml}$. Jurkat cells transfected with $\mathrm{Bcl}-2$ (Jurkat/Bcl-2) (a gift of John Reed, La Jolla, CA, USA) or with the empty transfection vector (Jurkat/control) and 4B1 cells (mouse WR19L cells overexpressing the human Fas-receptor) ${ }^{28}$ were cultured 
in the same medium with the addition of $200 \mu \mathrm{g} / \mathrm{ml} \mathrm{G} 418$ (Gibco-BRL). HeLa (human cervix carcinoma) cells and HL-60 (human promyelocytic leukemia) cells were grown in DMEM (Gibco-BRL) supplemented with $10 \%$ FCS, penicillin and streptomycin. Murine Neuro2A cells transfected with murine Fas-Ligand (FasL) (kindly provided by Dr. A Fontana, Zürich, Switzerland) or with the empty transfection vector (mock) were cultured in DMEM supplemented with $5 \%$ FCS, penicillin, streptomycin and $200 \mu \mathrm{g} / \mathrm{ml} \mathrm{G} 418 .{ }^{42}$ Cell lines were grown in a humidified $37^{\circ} \mathrm{C}$ incubator containing $5 \% \mathrm{CO}_{2}$.

\section{Induction of cell death}

To induce apoptosis, Jurkat suspension cells were seeded at a concentration of $1 \times 10^{6} / \mathrm{ml}$ and incubated either with: the monoclonal anti-Fas antibody 7C11 (a gift of Michael Robertson, Indiana University, Bloomington, IN, USA) at a final dilution of $1: 500$ as described, ${ }^{43}$ with murine FasL or mock supernatant (see below), with $10 \mu \mathrm{g} / \mathrm{ml}$ anisomycin, with $0.5 \mu \mathrm{M}$ staurosporine or with $100 \mu \mathrm{g} / \mathrm{ml}$ cycloheximide. HL-60 and 4B1 cells were treated with the anti-Fas antibody $7 \mathrm{C} 11$, HeLa cells and HL-60 cells were treated with $10 \mu \mathrm{g} / \mathrm{ml}$ anisomycin. Cells were incubated at $37^{\circ} \mathrm{C}$ for the indicated time periods before harvesting. After induction of cell death, cells were washed three times with PBS and used immediately or stored at $-70^{\circ} \mathrm{C}$.

For experiments utilizing the cell permeable tetrapeptide caspase inhibitors (Calbiochem), Jurkat cells $\left(1.5 \times 10^{6}\right.$ cells $\left./ \mathrm{ml}\right)$ were cultured for $1 \mathrm{~h}$ at $37^{\circ} \mathrm{C}$ in the presence of 5 and $20 \mu \mathrm{M} \mathrm{Ac-YVAD-CMK,} \mathrm{Z-}$ DEVD-FMK, Z-IETD-FMK, or Z-LEHD-FMK (irreversible inhibitors of caspases $1,3,8$ and 9 , respectively) in DMSO, prior to the induction of apoptosis with the monoclonal anti-Fas antibody $7 \mathrm{C} 11$. To minimize spontaneous cell death, cells were maintained at a concentration of $1 \times 10^{6}$ cells $/ \mathrm{ml}$ by diluting every $2-3$ days in fresh medium to maintain exponential cell growth.

\section{Production of murine Fas-Ligand (FasL)}

Murine FasL was obtained from murine FasL-transfected Neuro2A cells after 2 days of culture in DMEM supplemented with $5 \%$ FCS without G418. Supernatant was collected and cleared from cells and debris by centrifugation and used to induce apoptosis in Jurkat/control cells as described above. Supernatant from mock-transfected Neuro2A cells was used as control. Cells were incubated at $37^{\circ} \mathrm{C}$ for the indicated time periods before harvesting. After induction of cell death, cells were washed three times with PBS and used immediately or stored at $-70^{\circ} \mathrm{C}$.

\section{Flow cytometry}

Induction of apoptosis with the monoclonal anti-Fas antibody $7 \mathrm{C} 11$ in Jurkat/control cells, was monitored by staining the cells with annexin V-FITC $(1 \mu \mathrm{g} / \mathrm{ml})$ in RPMI, $10 \% \mathrm{FCS}, 2.5 \mathrm{mM} \mathrm{CaCl}_{2}$ for 2 min at room temperature, followed by propidium iodide $(5 \mu \mathrm{g} / \mathrm{ml})$ for $10 \mathrm{~min}$ at $4^{\circ} \mathrm{C}$. Staining was determined using a Coulter Epics Elite flow cytometer.

\section{Preparation of cell extracts and Western blot analysis}

Cells were lysed on ice for $30 \mathrm{~min}$ in NP-40 lysis buffer $(25 \mathrm{mM}$ Tris$\mathrm{HCl}, \mathrm{pH} 7.5,1 \% \mathrm{NP}-40,100 \mathrm{mM} \mathrm{KCl}, 10 \mathrm{mM} \mathrm{MgCl} 2,0.25 \mathrm{mM}$ DTE, containing the Complete protease inhibitor cocktail (Boehringer Mannheim)). Cell lysates were centrifuged for $15 \mathrm{~min}$ at $4^{\circ} \mathrm{C}$ (13000 r.p.m.) and the supernatants were used immediately or stored at $-70^{\circ} \mathrm{C}$. Protein extracts of $1 \times 10^{6}$ cells were sizefractionated by $10 \%$ SDS-PAGE and blotted onto nitrocellulose filters (Schleicher \& Schuell). Western blots were blocked in washing buffer (5\% skimmed milk, $50 \mathrm{mM}$ Tris, $150 \mathrm{mM} \mathrm{NaCl}, 0.5 \%$ Tween-20) and subsequently incubated either with: SLE patient serum H42 (antiU1-70K) or M78 (anti-U1-70K, anti-U1A, anti-U1C, anti-Sm-B/B') diluted 1:5000 in washing buffer, or with culture supernatant (diluted $1: 10$ in washing buffer) of one of the following mouse monoclonal antibodies: $9 \mathrm{~A} 9$ (anti-U1A/U2B" ${ }^{\prime \prime}{ }^{22}$ or KSm5 (anti-Sm-B/B'). ${ }^{24}$ Blocking and antibody incubation were each performed for $1 \mathrm{~h}$ at room temperature. After extensive washing (4 times $10 \mathrm{~min}$ ), blots were incubated with peroxidase-conjugated rabbit anti-human Ig antibodies (Dako) or with peroxidase-conjugated rabbit anti-mouse Ig antibodies for $1 \mathrm{~h}$ at room temperature. After washing (4 times $10 \mathrm{~min}$ ), bound secondary antibodies were visualized via chemoluminescence.

\section{Patient serum samples}

The serum samples $\mathrm{H} 42$ and M78 were provided by patients seen at the Department of Rheumatology and Internal Medicine of the Academic Hospital Nijmegen, The Netherlands. Diagnoses were reached as described by de Rooij et al. ${ }^{44}$

\section{Immunoprecipitation}

Protein A-agarose beads ( $20 \mu \mathrm{l}$ of $50 \%$ slurry, Kem-En-Tec) were coated with $200 \mu \mathrm{l}$ culture supernatant of one of the following mouse monoclonal antibodies: 9A9 (anti-U1A/U2B' ${ }^{\prime \prime}$, ${ }^{22} \mathrm{KSm} 2$ (anti-SmD1), ${ }^{24} \mathrm{KSm} 5$ (anti-Sm-B/B'), ${ }^{24} \mathrm{Y} 12$ (anti-Sm-B/B'/D1/D3), ${ }^{45} 2.73$ $\left(\right.$ anti-U1-70K) ${ }^{46}$ or with $1 \mathrm{ml}$ culture supernatant of mouse monoclonal anti-VSV-G-tag antibody, which was used to immobilize VSV-Gtagged human scFv antibody fragments. Since the anti-VSV-G-tag $\mathrm{mAb}$ was of the IgG1 isotype, the beads were precoated with rabbit anti-mouse IgG (Dako) for $2 \mathrm{~h}$ at $4{ }^{\circ} \mathrm{C}$. The periplasmic fractions of tagged ScFv anti-U1C (K36) ${ }^{23}$ and ScFv anti-U1-stemloop II $(\mathrm{Z} 5 \mathrm{scFv} 3)^{29}$ were coupled to protein A-agarose via the anti-VSV-Gtag antibodies for $2 \mathrm{~h}$ at $4^{\circ} \mathrm{C}$. Anti-2,2,7-trimethylguanosine (TMG) cap antibodies (20 $\mu \mathrm{g}$ of $\mathrm{H} 20$, Euro-Diagnostica BV) were coupled to $20 \mu \mathrm{l}$ protein A-agarose. Unless stated otherwise, all incubations were performed overnight at $4^{\circ} \mathrm{C}$ in IPP150 $(150 \mathrm{mM} \mathrm{NaCl}, 10 \mathrm{mM}$ Tris- $\mathrm{HCl}$, $\mathrm{pH} 8.0,0.1 \% \mathrm{NP}-40$ ) by end-over-end rotation. Between incubations, beads were washed three times with IPP150. Immunoprecipitations were carried out with $20 \mu \mathrm{l}$ of a $1 \times 10^{8}$ cell equivalents/ml Jurkat extract in IPP150 by end-over-end rotation for $2 \mathrm{~h}$ at $4^{\circ} \mathrm{C}$ and subsequently washed three times with IPP150. The beads were either resuspended in $100 \mu \mathrm{IPP} 150 / 0.5 \%$ SDS to isolate co-immunoprecipitated RNA via TRIzol (see below), or in $10 \mu \mathrm{l}$ SDS sample buffer to analyze protein complexes via SDS-PAGE and Western blotting. To analyze non-immunoprecipitated proteins after immunoprecipitation, the supernatant was precipitated with 5 volumes of acetone for $1 \mathrm{~h}$ at $-70^{\circ} \mathrm{C}$. After spinning for $15 \mathrm{~min}\left(13000\right.$ r.p.m.) at $4^{\circ} \mathrm{C}$, the samples were dried, dissolved in SDS sample buffer and analyzed by SDSPAGE and Western blotting.

\section{RNA isolation and Northern blot analysis}

RNA was isolated by direct addition of TRIzol reagent (Gibco-BRL) to cell lysates (see above) or immunoprecipitated U1 snRNP complexes, according to the manufacturer's specifications. RNA was size fractionated on $6 \%$ polyacrylamide $/ 8 \mathrm{M}$ urea gels, blotted onto Hybond $\mathrm{N}^{+}$filters (Amersham) and hybridized as described previously. ${ }^{47}$ Northern blots were washed with $2 \times$ SSC/1\% SDS 
(three times $20 \mathrm{~min}$ at $65^{\circ} \mathrm{C}$ ) and analyzed by autoradiography. In case of cell lysates, the total RNA of $0.5 \times 10^{6}$ cells was size fractionated.

\section{Probes}

To obtain antisense ${ }^{32} \mathrm{P}$-labeled human (h) U1, hU3, hU4 and hU6 RNA probes, the corresponding DNA constructs were linearized and $1 \mu \mathrm{g}$ was transcribed with either SP6 or T7 RNA polymerase in the presence of ${ }^{32} \mathrm{P}$-UTP essentially as described before. ${ }^{48}$ Xenopus laevis (x) U2 and hU5 DNA probes for hU2 snRNA and hU5 snRNA detection, were obtained after ${ }^{32} \mathrm{P}$-dCTP labeling of inserts isolated from the corresponding DNA constructs, using a random primed DNA labeling kit according to the manufacturer's instructions (Boehringer Mannheim).

\section{pCp labeling}

Immunoprecipitated RNA was 3 '-end labeled using ${ }^{32} \mathrm{P}-\mathrm{pCp}$ and T4 RNA ligase as described before. ${ }^{49}$

\section{Determination of the U1 snRNA cleavage site via nuclease protection}

Nuclease $\mathrm{S} 1$ mapping was performed as described before ${ }^{50}$ with some minor modifications. U1 snRNA (supplemented with $100 \mu \mathrm{g}$ yeast RNA) and yeast RNA (as control) were annealed with $2.5 \times 10^{4}$ c.p.m. of the $5^{\prime}$-end ${ }^{32} \mathrm{P}$-labeled antisense oligonucleotide 5'-CCTTCGTGATCATGGTATCTCCCCTGCCAGGTAAGTATC(A) ${ }_{10}$ $3^{\prime}$ at $40^{\circ} \mathrm{C}$ overnight. The first 39 nucleotides of this oligonucleotide are complementary to the $5^{\prime}$-end of the human U1 snRNA sequence. The ten A-residues at the $3^{\prime}$-end of the oligonucleotide were added to generate a protruding 3 '-end in the DNA-RNA hybrid. After overnight annealing, the non-hybridized regions of the oligonucleotide were digested by incubation with 1000 units/ml nuclease $\mathrm{S} 1$ (Boehringer Mannheim) for $1 \mathrm{~h}$ at $37^{\circ} \mathrm{C}$. The remaining products were electrophoresed in a $10 \%$ polyacrylamide/ $8 \mathrm{M}$ urea gel, which was subsequently exposed for autoradiography. As additional size markers, several $5^{\prime}$-end ${ }^{32} \mathrm{P}$-labeled oligonucleotides were used. Non-apoptotic and apoptotic Jurkat cell extracts or total RNA were used to isolate $\mathrm{U} 1$ snRNA either via immunoprecipitations with the monoclonal antibody $9 \mathrm{~A} 9$ (anti-U1A/U2B" ${ }^{\prime \prime}$, ${ }^{22}$ or via $6 \%$ polyacrylamide/8 $\mathrm{M}$ urea gel electrophoresis followed by RNA elution. All $5^{\prime}$-end ${ }^{32} \mathrm{P}$-labeled oligonucleotides were isolated by PAGE-purification. RNA and oligonucleotides were eluted from the gels by adding $200 \mu \mathrm{l}$ elution buffer $\left(500 \mathrm{mM} \mathrm{NH}_{4} \mathrm{Ac}, \mathrm{pH} 6.5,10 \mathrm{mM} \mathrm{MgCl} 2,0.1 \% \mathrm{SDS}\right.$, $0.5 \mu \mathrm{g} / \mu$ l yeast RNA) to the gel slices and incubating overnight at $4^{\circ} \mathrm{C}$.

\section{Acknowledgements}

We thank Dr. J Reed (La Jolla, CA, USA) for the Jurkat cell lines; Dr. M Robertson (Bloomington, IN, USA) for the anti-Fas mAb 7C11; Dr. W Hendriks (Nijmegen, The Netherlands) for the mouse 4B1 cell line; Dr. A Fontana (Zürich, Switzerland) for the mouse Neuro2A cells; Dr. M van Bruggen (Nijmegen, The Netherlands) for assistance with flow cytometry; Dr. J Raats (Nijmegen, The Netherlands) for advice; and M Hottelet (Boston, MA, USA), L Doerwald and P Piepers (Nijmegen, The Netherlands) for technical assistance. We thank Future Diagnostics B.V. (Wijchen, The Netherlands) for financial support to WGJ Degen. The work of WJ van Venrooij and GJM Pruijn was supported in part by the Netherlands Foundation for Chemical Research (SON) with financial aid from the Netherlands Organization for Scientific Research (NWO) and the Netherlands Technology Foundation (STW). The work of PJ Utz was supported by the Arthritis Foundation, the Scleroderma Foundation, Inc., National Institutes of Health Grant K08AI01521, the Arthritis National Research Foundation, and Harvard Skin Disease Research Center Grant AR42689.

\section{References}

1. Tan EM (1989) Antinuclear antibodies: diagnostic markers for autoimmune diseases and probes for cell biology. Adv. Immunol. 44: 93-152

2. van Venrooij WJ and Sillekens PT (1989) Small nuclear RNA associated proteins: autoantigens in connective tissue diseases. Clin. Exp. Rheumatol. 7: $635-645$

3. Hoet RMA, Kastner B, Luhrmann R and van Venrooij WJ (1993) Purification and characterization of human autoantibodies directed to specific regions on U1RNA; recognition of native U1RNP complexes. Nucleic. Acids. Res. 21: $5130-5136$

4. HoetRMA, De WeerdP, Klein Gunnewiek JMT, Koornneef I and van Venrooij WJ (1992) Epitope regions on U1 small nuclear RNA recognized by anti-U1RNAspecific autoantibodies. J. Clin. Invest. 90: 1753-1762

5. Hoet RMA, Koornneef I, de Rooij DJ, van de Putte LB and van Venrooij WJ (1992) Changes in anti-U1 RNA antibody levels correlate with disease activity in patients with systemic lupus erythematosus overlap syndrome. Arthritis Rheum. 35: $1202-1210$

6. Klein Gunnewiek JMT, van de Putte LB and van Venrooij WJ (1997) The U1 snRNP complex: an autoantigen in connective tissue diseases. An update. Clin. Exp. Rheumatol. 15: 549-560

7. Vaishnaw AK, McNally JD and Elkon KB (1997) Apoptosis in the rheumatic diseases. Arthritis Rheum. 40: 1917-1927

8. Casiano CA, Ochs RL and Tan EM (1998) Distinct cleavage products of nuclear proteins in apoptosis and necrosis revealed by autoantibody probes. Cell Death Differ. 5: 183-190

9. Casciola Rosen LA, Anhalt G and Rosen A (1994) Autoantigens targeted in systemic lupus erythematosus are clustered in two populations of surface structures on apoptotic keratinocytes. J. Exp. Med. 179: 13171330

10. Casciola Rosen LA, Anhalt GJ and Rosen A (1995) DNA-dependent protein kinase is one of a subset of autoantigens specifically cleaved early during apoptosis. J. Exp. Med. 182: 1625-1634

11. Casciola Rosen LA, Rosen A, Petri M and Schlissel M (1996) Surface blebs on apoptotic cells are sites of enhanced procoagulant activity: implications for coagulation events and antigenic spread in systemic lupus erythematosus. Proc. Natl. Acad. Sci. U.S.A. 93: 1624-1629

12. Cohen GM (1997) Caspases: the executioners of apoptosis. Biochem. J. 326: $1-16$

13. Utz PJ and Anderson P (1998) Posttranslational protein modifications, apoptosis, and the bypass of tolerance to autoantigens. Arthritis Rheum. 41: $1152-1160$

14. Sharp PA (1994) Split genes and RNA splicing. Cell 77: 805-815

15. Tazi J, Kornstadt U, Rossi F, Jeanteur P, Cathala G, Brunel $C$ and Luhrmann $R$ (1993) Thiophosphorylation of U1-70K protein inhibits pre-mRNA splicing. Nature 363: $283-286$

16. Casciola Rosen LA, Miller DK, Anhalt GJ and Rosen A (1994) Specific cleavage of the $70-\mathrm{kDa}$ protein component of the $\mathrm{U} 1$ small nuclear ribonucleoprotein is a characteristic biochemical feature of apoptotic cell death. J. Biol. Chem. 269: 30757-30760

17. Casciola Rosen LA, Nicholson DW, Chong T, Rowan KR, Thornberry NA, Miller DK and Rosen A (1996) Apopain/CPP32 cleaves proteins that are essential for cellular repair: a fundamental principle of apoptotic death. J. Exp. Med. 183: $1957-1964$

18. Utz PJ, Hottelet M, van Venrooij WJ and Anderson P (1998) Association of phosphorylated serine/arginine (SR) splicing factors with the U1-small ribonucleoprotein (snRNP) autoantigen complex accompanies apoptotic cell death. J. Exp. Med. 187: 547-560

19. Fadok VA, Voelker DR, Campbell PA, Cohen JJ, Bratton DL and Henson PM (1992) Exposure of phosphatidylserine on the surface of apoptotic lymphocytes triggers specific recognition and removal by macrophages. J. Immunol. 148: $2207-2216$ 
20. Vaux DL, Cory S and Adams JM (1988) Bcl-2 gene promotes haemopoietic cell survival and cooperates with c-myc to immortalize pre-B cells. Nature 335: 440 442

21. Hockenbery D, Nunez G, Milliman C, Schreiber RD and Korsmeyer SJ (1990) $\mathrm{Bcl}-2$ is an inner mitochondrial membrane protein that blocks programmed cell death. Nature 348: $334-336$

22. Habets WJ, HoetRMA, De Jong BA, Van der Kemp A and van Venrooij WJ (1989) Mapping of $B$ cell epitopes on small nuclear ribonucleoproteins that react with human autoantibodies as well as with experimentally-induced mouse monoclonal antibodies. J. Immunol. 143: 2560-2566

23. Hoet RMA, Raats JMH, de Wildt RM, Dumontier H, Muller S, van den Hoogen F and van Venrooij WJ (1999) Human monoclonal antibody fragments from combinatorial antibody libraries directed to the U1snRNP associated U1C protein; epitope mapping, immunolocalization and V-gene usage. Mol. Immunol. 35: $1045-1055$

24. Williams DG, Stocks MR, Smith PR and Maini RN (1986) Murine lupus monoclonal antibodies define five epitopes on two different Sm polypeptides. Immunology 58: 495-500

25. Casiano CA, Martin SJ, Green DR and Tan EM (1996) Selective cleavage of nuclear autoantigens during CD95 (Fas/APO- 1)-mediated T cell apoptosis. J. Exp. Med. 184: 765-770

26. Strasser A, Harris AW, Huang DC, KrammerPHand Cory S(1995)Bcl-2 and Fas/ APO-1 regulate distinct pathways to lymphocyte apoptosis. EMBO J. 14:61366147

27. Memon SA, Moreno MB, Petrak D and Zacharchuk CM (1995) Bcl-2 blocks glucocorticoid-butnotFas-or activation-induced apoptosis in a T cell hybridoma. J. Immunol. 155: 4644-4652

28. Cuppen E, Nagata S, Wieringa B and Hendriks W (1997) No evidence for involvement of mouse protein-tyrosine phosphatase-BAS-like Fas-associated phosphatase-1 in Fas-mediated apoptosis. J. Biol. Chem. 272: 30215-30220

29. Teunissen SW, Stassen MH, Pruijn GJM, van Venrooij WJ and Hoet RMA (1998) Characterization of an anti-RNA recombinant autoantibody fragment (scFv) isolated from a phage display library and detailed analysis of its binding site on U1 snRNA. RNA. 4: 1124-1133

30. Theissen H, Etzerodt M, Reuter R, Schneider C, Lottspeich F, Argos P, Luhrmann R and Philipson L (1986) Cloning of the human cDNA for the U1 RNAassociated 70K protein. EMBO J. 5: 3209-3217

31. Nelissen RL, Will CL, van Venrooij WJ and LuhrmannR(1994) The association of the U1-specific 70K and C proteins with U1 snRNPs is mediated in part by common U snRNP proteins. EMBO J. 13: 4113-4125

32. Reddy R and Busch H (1988) Small nuclear RNAs: RNA sequences, structure and modifications. In: Structure and function of major and minor small nuclear ribonucleoprotein particles. Birnstiel ML (ed). Springer-Verlag Press. pp. 1-37

33. Massenet S, Mougin A and Branlant C (1998) Posttranscriptional modifications in the U small nuclear RNAs. In: Modification and editing of RNA. Grosjean $\mathrm{H}$ and Benne R (eds). ASM Press. pp. 201-227

34. Crawford DR, Lauzon RJ, Wang Y, Mazurkiewicz JE, Schools GP and Davies KJ (1997) 16S mitochondrial ribosomal RNA degradation is associated with apoptosis. Free Radic. Biol. Med. 22: 1295-1300

35. Houge G, Doskeland SO, Boe R and Lanotte M (1993) Selective cleavage of $28 \mathrm{~S}$ rRNA variable regions $\mathrm{V} 3$ and $\mathrm{V} 13$ in myeloid leukemia cell apoptosis. FEBS Lett. 315: $16-20$
36. Houge G, Robaye B, Eikhom TS, Golstein J, Mellgren G, Gjertsen BT, Lanotte M and Doskeland SO (1995) Fine mapping of 28S rRNA sites specifically cleaved in cells undergoing apoptosis. Mol. Cell Biol. 15: 2051-2062

37. Rutjes SA, van der Heijden A, Utz PJ, van Venrooij WJ and Pruijn GJM (1999) Rapid nucleolytic degradation of the small cytoplasmic $Y$ RNAs during apoptosis. J. Biol. Chem. 274: 24799-24807

38. Guthrie C and Patterson B (1988) Spliceosomal snRNAs. Annu. Rev. Genet. 22: $387-419$

39. Lamond Al (1993) The spliceosome. Bioessays 15: 595-603

40. Steitz JA, Black DL, Gerke V, Parker KA, Kramer A, Frendewey D and Keller W (1988) Functions of abundantU-snRNPs. In: Structure and function of major and minor small nuclear ribonucleoprotein particels. Birnstiel ML (ed). SpringerVerlag Press. pp. 115-154

41. Temsamani J, Agrawal S and Pederson T (1991) Biotinylated antisense methylphosphonate oligodeoxynucleotides. Inhibition of spliceosome assembly and affinity selection of U1 and U2 small nuclear RNPs. J. Biol. Chem. 266: 468 472

42. Rensing-Ehl A, Frei K, Flury R, Matiba B, Mariani SM, Weller M, Aebischer P, Krammer PH and Fontana A (1995) Local Fas/APO-1 (CD95) ligand-mediated tumor cell killing in vivo. Eur. J. Immunol. 25: 2253-2258

43. Utz PJ, Hottelet M, Schur PH and Anderson P (1997) Proteins phosphorylated during stress-induced apoptosis are common targets for autoantibody production in patients with systemic lupus erythematosus. J. Exp. Med. 185: $843-854$

44. de Rooij DJ, van de Putte LB, Habets WJ, Verbeek AL and van Venrooij WJ (1988) The use of immunoblotting to detect antibodies to nuclear and cytoplasmic antigens. Clinical and serological associations in rheumatic diseases. Scand. J. Rheumatol. 17: 353-364

45. Lerner EA, Lerner MR, Janeway Jr CA and Steitz JA (1981) Monoclonal antibodies to nucleic acid-containing cellular constituents: probes for molecular biology and autoimmune disease. Proc. Natl. Acad. Sci. U.S.A. 78: 2737-2741

46. Billings PB, Allen RW, Jensen FC and Hoch SO (1982) Anti-RNP monoclona antibodies derived from a mouse strain with lupus-like autoimmunity. J. Immunol. 128: $1176-1180$

47. Degen WGJ, Weterman MA, van Groningen JJ, Cornelissen IM, Lemmers JP, Agterbos MA, Geurts van Kessel A, Swart GW and Bloemers HP (1996) Expression of nma, a novel gene, inversely correlates with the metastatic potential of human melanoma cell lines and xenografts. Int. J. Cancer 65: 460465

48. de Wildt RM, Finnern R, Ouwehand WH, Griffiths AD, van Venrooij WJ and Hoet RMA (1996) Characterization of human variable domain antibody fragments against the U1 RNA-associated A protein, selected from a synthetic and patientderived combinatorial V gene library. Eur. J. Immunol. 26: 629-639

49. van Gelder CW, Thijssen JP, Klaassen EC, Sturchler C, Krol A, van Venrooij WJ and Pruijn GJM (1994) Common structural features of the Ro RNP associated hY1 and hY5 RNAs. Nucleic. Acids. Res. 22: 2498-2506

50. Boelens WC, Jansen EJ, van Venrooij WJ, Stripecke R, Mattaj IW and Gunderson SI (1993) The human U1 snRNP-specific U1A protein inhibits polyadenylation of its own pre-mRNA. Cell 72: $881-892$ 